\title{
The Influence of Fertilizers on Tobacco Yields
}

\author{
P. Landrau, Jr., G. Samuels, S. Alers-Alers, and C. González-Molina ${ }^{1}$
} INTRODUCTION

Tobacco is one of the most important cash crops in Puerto Rico. In $1956-57$, with a farm value of $\$ 7,402,000$, it ranked third, coming after sugarcane and coffee. Most of the tobacco grown in Puerto Rico is cigarleaf tobacco, known as U.S. type 46, and is used as filler in the cigarmanufacturing industry both in Puerto Rico and the United States. This tobacco is grown generally in the humid semihighlands of the interior part of the Island. A small quantity of tobacco is grown for chewing purposes in two small coastal areas in the northwestern and southwestern parts of the Island.

In $1955-56,36,100$ acres were devoted to tobacco. There were over 24,000 individual tobacco growers; over 85 percent of them farmed less than 3 acres of tobacco. These small farmers who raise a few minor crops and fruits derived 75 percent of their cash income from tobacco. Other crops following tobacco in importance on these small farms are corn, sweetpotatoes, coffee, and bananas.

Tobacco is a shallow-rooted crop compared to citrus or sugarcane, and it can grow and produce fair to good yields on soils of steep hillsides. However, for good yields fertilizers must be used. About 20 percent of the costs of growing tobacco is tied up in fertilizers; this ranks second only to labor with 46 percent as the highest cost in growing tobacco (B). ${ }^{2}$

\section{OBJECTIVES}

In view of the importance of this crop to the agricultural economy of the Island, the Agronomy and Horticulture Department undertook a series of experiments to determine the fertilizer requirements of tobacco. This paper deals with the response of tobacco to major-element $\left(\mathrm{N}-\mathrm{P}_{2} \mathrm{O}_{5}-\mathrm{K}_{2} \mathrm{O}\right)$ fertilizer applications on a Juncos clay at Aibonito, as well as sources of nitrogen and potash and minor elements on a Caguas and Mabi clay.

\section{PROCEDURE}

There were five experiments in all covering the tobacco fertilizer investigations. The first three were carried out at the former Aibonito Farm of

1 Associate Agronomist, Agronomist, Research Assistant in Agronomy II, and Research Assistant in Agronomy I, respectively, Agricultural Experiment Station, University of Puerto Rico, Río Piedras, P. R. The authors wish to thank A. S. Amy, Associate Agronomist, for his help and advice on tobacco culture.

2 Italic numbers in parentheses refer to Literature Cited, p. 68. 
the Agricultural Experiment Station (elevation 2,000 feet). The first experiment was planted on November 28,1951 , and the last picking was made 119 days later, on March 26, 1952; the second experiment was planted on January 4, 1952, and the last picking was made 128 days later, on April 16, 1953; the third experiment was planted on November 4, 1953, and the last picking was made 102 days later, on March 18, 1954. The experiments were repeated each year using the same plots and fertilizer treatments. The treatments were mainly devoted to different levels of $\mathrm{N}-\mathrm{P}_{2} \mathrm{O}_{5}-\mathrm{K}_{2} \mathrm{O}$ and time of application.

The tobacco variety Virginia 12 was used because in recent years it has been the most extensively cultivated variety in Puerto Rico. This variety is primarily of the cigar-filler type.

The soil used was classified as a Juncos clay. It is a heavy, acid soil (pH 5.6) associated with the extensive Múcara soils of the mountainous area and with the Mabi soils of the valleys. These soils are mainly cropped to sugarcane, tobacco, and subsistance crops.

The experiments were laid out in a triple-lattice design with 25 fertilizer treatments replicated 6 times, making 150 plots in all. The plot size was 14 feet wide and 20 feet long, or approximately $1 / 150$ acre in area. Each plot had 4 rows, 42 inches apart, with 12 tobacco plants 18 inches apart in the row, making a total of 48 plants per plot. Seedlings were selected as to uniformity in regard to size and development and carefully transplanted to the experimental plots. All mosaic-infected plants were discarded. Seedlings were replanted, if needed, 10 days after the first planting.

To control cutworms, ants, and mole crickets the soil was treated with Aldrin at the rate per acre of 1 gallon dissolved in 50 gallons of water. The plants were also sprayed periodically with a solution of Isotox when an aphid infestation was noticed.

The fertilizers were applied in the soil 10 days after planting the tobacco seedlings, except where otherwise noted in the treatments. The fertilizer was placed in small semicircular bands at opposite sides of the plant and then covered with soil. The fertilizer sources were ammonium sulfate (20-percent $\mathrm{N}$ ), superphosphate (20-percent $\left.\mathrm{P}_{2} \mathrm{O}_{5}\right)$, and potassium sulfate (50-percent $\mathrm{K}_{2} \mathrm{O}$ ). The ground limestone used contained 93 percent of $\mathrm{CaCO}_{3}$, and was applied before planting and thoroughly incorporated with a hoe into the upper 3 inches of soil.

The tobacco leaves were picked every 8 to 10 days after the first picking was made. All plants were pinched back (topped) after they were fully grown, to prevent flowering and induce enlargement of the leaves. Usually the first picking came about $1 \frac{1}{2}$ months after field planting, and the number of pickings depended principally on the growth and development of the plant. The tobacco leaves collected from each plot at each picking 
were properly identified and hung in racks in the tobacco barn for drying. After the leaves were dried they were tied in bundles and weight data recorded.

The fourth experiment was conducted at the former Tobacco Farm at Caguas. The soil used was a Caguas clay, a gray weakly granular acid clay which is very plastic when wet. The soil $\mathrm{pH}$ was about 5.6.

The fifth experiment was performed at the Gurabo Substation Farm. The soil used was a Mabí clay, with a pH 5.1. This soil is a grayish-brown plastic heavy clay which has good tilth when properly plowed and cultivated.

For both the fourth and fifth experiments experimental design and plot size were the same as for the first three at Aibonito. In fact, no difference in general procedure was practiced except for changes in fertilizer treatments used. The Caguas and Gurabo experiments were primarily devoted to testing sources of nitrogen and potash, minor elements, and liming materials.

\section{RESULTS}

\section{MAJOR-ELEMENT FERTILIZERS}

\section{Nitrogen}

There was a definite response of tobacco to nitrogen fertilizer as can be seen in table 1. The increase from the use of 50 pounds of nitrogen per acre as compared to no nitrogen was very significant. For the average of three crops the increase was 5.87 hundredweights, or 76 percent more tobacco as compared to no nitrogen. The use of 100 pounds of nitrogen or more per acre did not give any significant increases in yields over that of the 50-pound rate. It appears that for all practical purposes 50 pounds per acre of nitrogen is adequate for high tobacco yields and that rates of 100 pounds per acre and above are not needed.

\section{Phosphorus}

The use of 50 pounds per acre of $\mathrm{P}_{2} \mathrm{O}_{6}$ gave a significant response in yields of tobacco in all three experiments at Aibonito (table 1). No appreciable increase was obtained when 100 pounds of $\mathrm{P}_{2} \mathrm{O}_{5}$ per acre was compared to the 50-pound-per-acre rate. In fact, an average increase of only 0.8 hundredweight was obtained for the three crops when 50 more pounds of $\mathrm{P}_{2} \mathrm{O}_{5}$ per acre was used above that of the original 50 pounds per acre. For phosphate response in tobacco the use of 50 pounds of $\mathrm{P}_{2} \mathrm{O}_{5}$ per acre appears to be optimum in these experiments. 


\section{Potassium}

No response was obtained from the use of potash. The use of even 150 pounds of $\mathrm{K}_{2} \mathrm{O}$ per acre failed to produce any significant response in

TABLE 1.-The influence of major-element fertilizers (N-P-K) on the yield (hundredweights) of tobacco, Aibonito experiments, 1951-54

\begin{tabular}{|c|c|c|c|c|c|c|}
\hline \multicolumn{3}{|c|}{ Fertilizer treatments in pounds per acre of- } & \multicolumn{4}{|c|}{ Mean yield of cured tobacco per acre } \\
\hline $\mathbf{N}$ & $\mathrm{P}_{2} \mathrm{O}_{3}$ & $\mathrm{~K}_{2} \mathrm{O}$ & $\begin{array}{l}\text { First crop, } \\
1951-52\end{array}$ & $\begin{array}{l}\text { Second crop, } \\
1952-53\end{array}$ & $\begin{array}{l}\text { Third crop, } \\
1953-54\end{array}$ & $\begin{array}{l}\text { Mean of } \\
3 \text { crops }\end{array}$ \\
\hline \multicolumn{7}{|c|}{ Nitrogen $(N)$} \\
\hline $\begin{array}{r}0 \\
50 \\
100 \\
150\end{array}$ & $\begin{array}{l}100 \\
100 \\
100 \\
100\end{array}$ & $\begin{array}{l}150 \\
150 \\
150 \\
150\end{array}$ & $\begin{array}{r}6.34 \\
12.60 \\
12.38 \\
13.54\end{array}$ & $\begin{array}{r}8.26 \\
10.08 \\
10.50 \\
10.44\end{array}$ & $\begin{array}{r}8.77 \\
18.30 \\
20.60 \\
20.16\end{array}$ & $\begin{array}{r}7.79 \\
13.66 \\
14.49 \\
14.71\end{array}$ \\
\hline \multicolumn{7}{|c|}{ Phosphorus $\left(P_{2} \mathrm{O}_{6}\right)$} \\
\hline $\begin{array}{l}150 \\
150 \\
150 \\
150\end{array}$ & $\begin{array}{r}0 \\
50 \\
100 \\
150\end{array}$ & $\begin{array}{l}150 \\
150 \\
150 \\
150\end{array}$ & $\begin{array}{c}10.80 \\
12.76 \\
13.54 \\
-\end{array}$ & $\begin{array}{r}8.61 \\
9.92 \\
10.44 \\
10.08\end{array}$ & $\begin{array}{c}13.50 \\
19.04 \\
20.16 \\
-\end{array}$ & $\begin{array}{c}10.97 \\
13.91 \\
14.71 \\
-\end{array}$ \\
\hline \multicolumn{7}{|c|}{ Polassium $\left(\mathrm{K}_{2} \mathrm{O}\right)$} \\
\hline $\begin{array}{l}150 \\
150 \\
150 \\
150\end{array}$ & $\begin{array}{l}100 \\
100 \\
100 \\
100\end{array}$ & $\begin{array}{r}0 \\
50 \\
100 \\
150\end{array}$ & $\begin{array}{l}12.43 \\
13.71 \\
12.77 \\
13.54\end{array}$ & $\begin{array}{l}10.29 \\
10.43 \\
10.64 \\
10.44\end{array}$ & $\begin{array}{l}18.33 \\
19.73 \\
20.42 \\
20.16\end{array}$ & $\begin{array}{l}13.68 \\
14.62 \\
14.61 \\
14.71\end{array}$ \\
\hline \multicolumn{3}{|c|}{ Average of all treatments.......... } & 11.93 & 9.91 & 17.65 & 13.16 \\
\hline \multicolumn{3}{|c|}{$\begin{array}{r}\text { Least significant difference needed } \\
\text { for comparison of treatments: } \\
\text { 5-percent level............... } \\
\text { 1-percent level............... }\end{array}$} & $\begin{array}{l}2.17 \\
2.87\end{array}$ & $\begin{array}{l}1.31 \\
1.72\end{array}$ & $\begin{array}{l}3.29 \\
4.34\end{array}$ & $\begin{array}{l}2.40 \\
3.12\end{array}$ \\
\hline
\end{tabular}

any of the three experiments. The average for the three experiments was only 0.94 hundredweight per acre more for the use of 50 pounds of $\mathrm{K}_{2} \mathrm{O}$ per acre. Rates up to 150 pounds of $K_{2} \mathrm{O}$ per acre failed to raise the yields. Although potash is known to be needed in large amounts by tobacco for improvement the burning quality, we can assume that as far as yields are concerned in Juncos clay, the available potash levels in the soil are adequate at present. 
TIME OF FERTILIZER APPLICATION

It is the normal practice in the tobacco areas for many farmers to delay application of their fertilizer for 10 to 15 days after planting. Also practiced is the splitting of the fertilizer application into two equal parts-one at time of planting, the second about 10 to 15 days later. The reason given for these practices is to prevent loss of fertilizer by leaching or erosion. For the Juncos clay at Aibonito it was clearly shown that putting all the fertilizer in the hole at time of planting gave no significantly different yields than other times of fertilizer application (table 2).

TABLE 2.-The influence of the time of fertilizer application on the yield (hundredweights) of tobacco, Aibonito experiments 1951-53

\begin{tabular}{|c|c|c|c|c|}
\hline \multirow{2}{*}{ Time of application? } & \multicolumn{4}{|c|}{ Mean yield of cured tobacco per acre } \\
\hline & First crop & Second crop & Third crop & Mean of 3 crops \\
\hline $\begin{array}{l}\text { All at time of planting } \\
10 \text { days after planting } \\
3 / 2 \text { at planting and } 1 / 210 \text { days after } \\
\text { planting }\end{array}$ & $\begin{array}{l}13.56 \\
12.38 \\
14.69\end{array}$ & $\begin{array}{r}9.62 \\
10.50 \\
10.74\end{array}$ & $\begin{array}{l}19.40 \\
20.60 \\
20.38\end{array}$ & $\begin{array}{l}14.53 \\
14.49 \\
15.27\end{array}$ \\
\hline 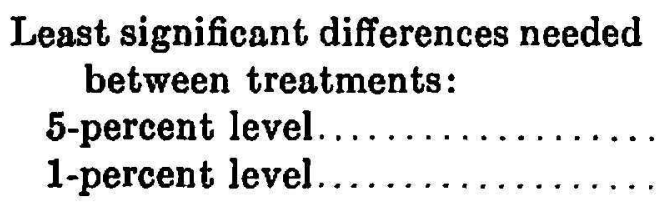 & $\begin{array}{l}2.17 \\
2.87\end{array}$ & $\begin{array}{l}1.31 \\
1.72\end{array}$ & $\begin{array}{l}3.29 \\
4.34\end{array}$ & $\begin{array}{l}2.40 \\
3.12\end{array}$ \\
\hline
\end{tabular}

${ }_{1}^{1}$ All treatments received a total of $100 \mathrm{lb}$. each of $\mathrm{N}$ and $\mathrm{P}_{2} \mathrm{O}_{5}$ and $150 \mathrm{lb}$. of $\mathrm{K}_{2} \mathrm{O}$ per acre.

Both time and money could be saved by the farmer applying his fertilizer at planting time rather than using split or late applications. Of course, sufficient care should be practiced in so placing the fertilizer that burning of the tobacco roots does not occur. Also, the practices of a single fertilizer application is not yet recommended for sandy soils or where heavy leaching has occurred.

\section{SOURCES OF NITROGEN}

Ammonium sulfate has been the standard nitrogen source in Puerto Rico for many years. In the past few years new nitrogen sources have become available on the fertilizer market. These materials were tested against ammonium sulfate as a standard, using equivalent amounts of nitrogen per acre, 100 pounds of $\mathrm{N}$ per acre, and in the presence of adequate phosphate and potash, 100 pounds of $\mathrm{P}_{2} \mathrm{O}_{5}$ per acre and 150 pounds of 
TABLE 3.-The influence of the source of nitrogen on the yield (hundredweights) of tobacco, Aibonito experiments, 1951-63, and others

\begin{tabular}{|c|c|c|c|c|c|c|c|}
\hline \multirow{3}{*}{ Source of nitrogen ${ }^{1}$} & \multirow{3}{*}{$\begin{array}{c}\text { Percentage } \\
\text { nitrogen } \\
\text { content }\end{array}$} & \multicolumn{6}{|c|}{$\begin{array}{l}\text { Relative yicld of cured tobacco per acre } \\
\text { (ammonium sulfate }=100 \text { ) }\end{array}$} \\
\hline & & \multicolumn{3}{|c|}{ Aibonito experiments } & \multirow{2}{*}{$\begin{array}{c}\text { Caguas } \\
\text { experi- } \\
\text { ment } \\
1954\end{array}$} & \multirow{2}{*}{$\begin{array}{c}\text { Gurabo } \\
\text { experi- } \\
\text { ment } \\
1955\end{array}$} & \multirow{2}{*}{$\begin{array}{l}\text { Average } \\
\text { of all } \\
\text { crops }\end{array}$} \\
\hline & & $\begin{array}{l}\text { First, } \\
1951\end{array}$ & $\begin{array}{c}\text { Second, } \\
1952\end{array}$ & Third, & & & \\
\hline \multicolumn{8}{|c|}{ Inorganic } \\
\hline Ammonium sulfate & 20 & 100 & 100 & 100 & 100 & 100 & 100 \\
\hline Ammonium nitrate & 33 & - & - & - & 94 & 110 & 102 \\
\hline Ammonium sulfate nitrate & 25 & - & - & 一 & 99 & 104 & 102 \\
\hline Calcium ammonium nitrate & 20 & - & - & - & 91 & 100 & 96 \\
\hline Calcium cyanamide & 18 & - & 65 & 97 & 41 & 50 & 63 \\
\hline Calcium nitrate & 15 & - & - & - & 94 & 79 & 87 \\
\hline Potassium nitrate & 14 & - & - & - & 90 & 88 & 89 \\
\hline Sodium nitrate & 16 & - & - & - & 90 & 86 & 88 \\
\hline Urea & 46 & 71 & 75 & 94 & 69 & 83 & 78 \\
\hline
\end{tabular}

\section{Organic}

\begin{tabular}{l|l|l|l|l|l|l|l|l}
\hline Castor pomace & 5 & - & - & - & 91 & 98 & 95 \\
Cottonseed meal & 7 & - & - & - & 98 & 92 & 95 \\
Filter-press cake & 2 & 77 & 100 & 68 & 83 & 70 & 80 \\
\hline
\end{tabular}

Mixtures

\begin{tabular}{|c|c|c|c|c|c|c|c|}
\hline $\begin{array}{l}1 / 2 \text { ammonium sulfate plus } 1 / 2 \\
\text { cottonseed meal }\end{array}$ & - & - & - & - & 97 & 105 & 101 \\
\hline $\begin{array}{l}1 / 2 \text { ammonium sulfate plus } 1 / 2 \\
\text { filter-press cake }\end{array}$ & - & 93 & 100 & 85 & - & - & 93 \\
\hline 3/2 urea plus $1 / 2$ cottonseed meal & - & - & - & - & 88 & 99 & 94 \\
\hline $\begin{array}{l}1 / 3 \text { urea plus } 1 / 3 \text { ammonium sul- } \\
\text { fate plus } 1 / 3 \text { sodium nitrate }\end{array}$ & - & - & - & - & 95 & 97 & 96 \\
\hline
\end{tabular}

Control

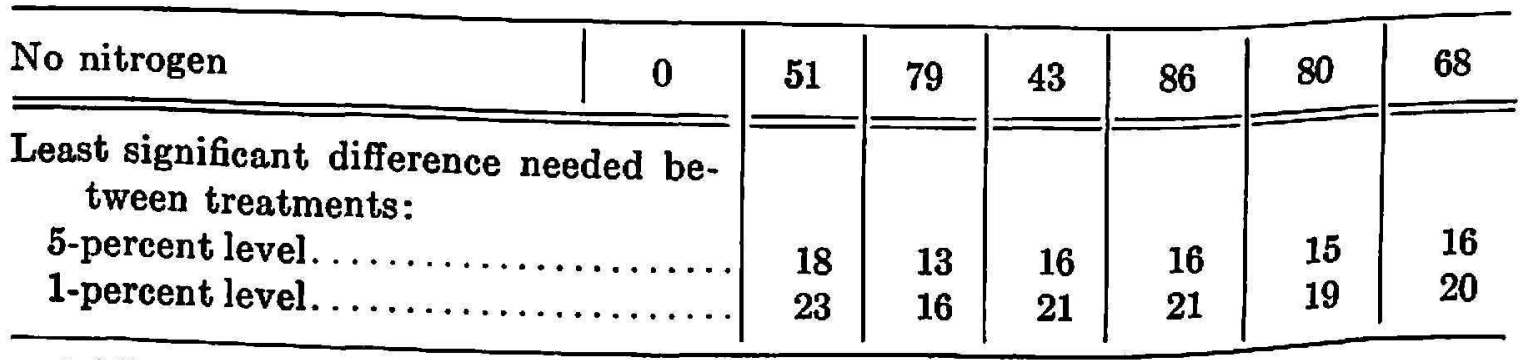

${ }^{1}$ All treatments received $100 \mathrm{lb}$. each of $\mathrm{N}$ and $\mathrm{P}_{2} \mathrm{O}_{5}$ and $150 \mathrm{lb}$. of $\mathrm{K}_{2} \mathrm{O}$ per acre. 
$\mathrm{K}_{2} \mathrm{O}$ per acre. To facilitate comparisons the actual yield of tobacco per acre for the ammonium sulfate treatment was assigned a value of 100 . The relative yields of the other treatments were then calculated using the ammonium sulfate standard of 100 as a base. The results obtained are given in table 3.

\section{Inorganic or Synthetic Organic}

No source of nitrogen used proved significantly superior to ammonium sulfate in promoting yield of cured tobacco per acre (table 3).

There were, however, several nitrogen sources that were significantly inferior to ammonium sulfate in increasing tobacco yields. Calcium cyanamide decreased yields in every experiment, giving an average reduction in yield of 37 percent. Urea also reduced yields 22 percent. For both nitrogen sources, calcium cyanamide and urea, the reduction in yield was negligible for the third experiment at Aibonito (table 3 ) where total rainfall was the highest for all five experiments. The failure of urea to give responses at least equal to ammonium sulfate is puzzling, inasmuch as urea has proven to be an outstanding nitrogen source for tobacco in Florida (2) and Connecticut (1).

\section{Organic}

Organic sources of nitrogen have long been advocated as necessary for production of tobacco of high quality in Connecticut (7) and Virginia (5). Animal manures, castor pomace, cottonseed meal, and fishmeal are common organic fertilizers used as nitrogen sources by tobacco growers in the United States. In Puerto Rico these organic sources of nitrogen have not been used, primarily because of their local unavailability and high price per ton when imported due to its bulk.

Castor pomace and cottonseed meal were tried as nitrogen sources along with filter-press cake, a local organic material obtained as a byproduct of the sugarcane mills $(6)$. As seen in table 3 no superior yields were obtained with these materials as compared with ammonium sulfate. In fact filterpress cake gave significantly lower yields than did ammonium sulfate. This may have been due to failure of the material to decompose rapidly enough to supply nitrogen to the tobacco plant.

\section{Mixtures}

The use of mixed sources of nitrogen (inorganic and organic) has been recommended for tobacco because it was felt that the inorganic nitrogen was readily available for immediate growth needs and the organic sources provided nitrogen - a slow steady supply resistant to leaching for use later on in the plant's growth. Various mixtures of organic and inorganic nitrogen 
sources were tried as shown in table 3 . None of the mixtures used proved superior to ammonium sulfate.

\section{SOURCES OF POTASSIUM}

Potassium sulfate has become the accepted standard source of potash for tobacco in Puerto Rico. Potassium chloride is not used as a potash source because of the harmful effect of the chlorine on tobacco quality

TABLE 4.-The influence of various sources of potassium on the yield (hundredweights) of tobacco, Aibonito experiments, 1951-58, and others

\begin{tabular}{|c|c|c|c|c|c|c|c|}
\hline \multirow{3}{*}{ Source of potassium² } & \multirow{3}{*}{ 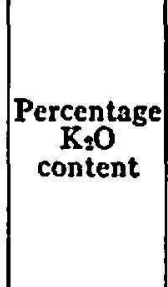 } & \multicolumn{6}{|c|}{$\begin{array}{l}\text { Relative yield of cured tobacco per acre } \\
\text { (potassium sulfate }=100 \text { ) }\end{array}$} \\
\hline & & \multicolumn{3}{|c|}{ Aibonito experiments } & \multirow{2}{*}{$\begin{array}{c}\text { Caguas } \\
\text { experi- } \\
\text { ment } \\
1954\end{array}$} & \multirow{2}{*}{$\begin{array}{c}\text { Gurabo } \\
\text { experi- } \\
\text { ment } \\
1955\end{array}$} & \multirow{2}{*}{$\begin{array}{l}\text { Average } \\
\text { of all } \\
\text { crops }\end{array}$} \\
\hline & & $\begin{array}{l}\text { First, } \\
1951\end{array}$ & $\begin{array}{l}\text { Second, } \\
1952\end{array}$ & Third, & & & \\
\hline Potassium sulfate & 50 & 100 & 100 & 100 & 100 & 100 & 100 \\
\hline Potassium nitrate & 46 & - & - & - & 91 & 88 & 90 \\
\hline Sulfo-mag ${ }^{2}$ & 22 & - & - & - & 91 & 101 & 96 \\
\hline Tobacco stems, unground & 7 & 97 & 92 & 97 & - & - & 95 \\
\hline Tobacco stems, ground & 7 & 123 & 96 & 105 & - & - & 108 \\
\hline $\begin{array}{l}1 / 2 \text { tobacco stems, ground plus } \\
1 / 2 \text { potassium sulfate }\end{array}$ & - & 107 & 87 & 101 & - & - & 98 \\
\hline No potash & 0 & 100 & 98 & 89 & - & - & 96 \\
\hline \multirow{3}{*}{\multicolumn{2}{|c|}{$\begin{array}{l}\text { Least significant differences needed be- } \\
\text { tween treatments: } \\
\text { 5-percent level } \ldots \ldots \ldots \ldots \ldots \ldots \ldots \ldots \ldots \ldots \ldots \ldots \ldots \\
\text { 1-percent level } \ldots \ldots \ldots \ldots \ldots \ldots \ldots\end{array}$}} & & & & & & \\
\hline & & 18 & 13 & 16 & 16 & 15 & 16 \\
\hline & & 23 & 16 & 21 & 21 & 19 & 20 \\
\hline
\end{tabular}

${ }^{1}$ All treatments received $100 \mathrm{lb}$. each of $\mathrm{N}$ and $\mathrm{P}_{2} \mathrm{O}_{3}$ and $150 \mathrm{lb}$. of $\mathrm{K}_{2} \mathrm{O}$ per acre.

${ }^{2}$ A double sulfate of potash and magnesia containing not less than 21 percent of $\mathrm{K}_{2} \mathrm{O}$ and not less than 53 percent of magnesium sulfate.

(4). Potassium chloride, or muriate of potash, as it is more commonly known, contains about 47 percent of chlorine. However, research has shown that small amounts of chlorine, up to 20 pounds per acre, can be of value (2).

Tested as potash sources aside from potassium sulfate were potassium nitrate, Sulfo-mag (a potassium-magnesium sulfate), and tobacco stems. None of the sources tested gave any significant increase in yield (table 4). Inasmuch as potash supplies in the soil appeared to be sufficient for the soils tested, none of the added potash sources was needed, and therefore, it was not possible to determine whether the source of potash influenced yields. 


\section{LIMING MATERLALS}

Many of the tobacco soils of Puerto Rico are quite acid ( $\mathrm{pH}$ below 5.5), and, therefore, one should expect some responses from liming for tobacco.

TABLE 5.-The influence of liming materials and minor elements on the yield (hundredweights) of tobacco, Aibonito experiments, 1951-58, and others

\begin{tabular}{|c|c|c|c|c|c|c|c|}
\hline \multirow{3}{*}{ Material } & \multirow{3}{*}{$\begin{array}{l}\text { Pounds } \\
\text { per acre }\end{array}$} & \multicolumn{6}{|c|}{$\begin{array}{l}\text { Relative yield of cured tobacco per acre } \\
\text { (no lime or minor clement }=100 \text { ) }\end{array}$} \\
\hline & & \multicolumn{3}{|c|}{ Aibonito experiments } & \multirow{2}{*}{$\begin{array}{c}\text { Caguas } \\
\text { experi- } \\
\text { ment } \\
1954\end{array}$} & \multirow{2}{*}{$\begin{array}{c}\text { Gurabo } \\
\text { experi- } \\
\text { ment } \\
1955\end{array}$} & \multirow{2}{*}{$\begin{array}{l}\text { Average } \\
\text { of all } \\
\text { crops }\end{array}$} \\
\hline & & $\begin{array}{l}\text { First, } \\
1951\end{array}$ & $\begin{array}{l}\text { Second, } \\
1952\end{array}$ & $\begin{array}{l}\text { Third, } \\
1953\end{array}$ & & & \\
\hline \multicolumn{8}{|c|}{ Liming materials } \\
\hline No lime & & 100 & 100 & 100 & 100 & 100 & 100 \\
\hline Lime $\left(\mathrm{CaCO}_{3}\right)$ & 2,000 & 120 & 107 & 116 & 89 & 80 & 104 \\
\hline Do. & 4,000 & 118 & 107 & 110 & - & - & 112 \\
\hline Gypsum $\left(\mathrm{CaSO}_{4} \cdot 2 \mathrm{H}_{2} \mathrm{O}\right)$ & 2,000 & - & - & - & 91 & 108 & 100 \\
\hline Lime plus gypsum & $\begin{array}{l}2,000 \\
2,000\end{array}$ & - & - & - & 101 & 81 & 91 \\
\hline Lime plus filter-press cake & $\begin{array}{l}2,000 \\
6,000\end{array}$ & - & 一 & 75 & 一 & - & 75 \\
\hline \multicolumn{8}{|c|}{ Minor elements } \\
\hline Magnesium oxide & 300 & 103 & 91 & 99 & - & - & 98 \\
\hline Sulfo-mag² & 450 & - & - & - & 91 & 101 & 96 \\
\hline Borax & 35 & 95 & - & - & - & - & 95 \\
\hline F.T.E.3 & 100 & 一 & - & - & 98 & 102 & 100 \\
\hline Miller Mineral Mix & 100 & - & - & - & 98 & 101 & 100 \\
\hline \multicolumn{2}{|c|}{$\begin{array}{l}\text { Least significant difference needed be- } \\
\text { tween treatments: } \\
\text { 5-percent level. } \ldots \ldots \ldots \ldots \ldots \ldots \ldots \ldots \\
\text { 1-percent level. } \ldots \ldots \ldots \ldots \ldots \ldots \ldots\end{array}$} & $\begin{array}{l}18 \\
23\end{array}$ & $\begin{array}{l}13 \\
16\end{array}$ & $\begin{array}{l}16 \\
21\end{array}$ & $\begin{array}{l}16 \\
21\end{array}$ & $\begin{array}{l}15 \\
19\end{array}$ & $\begin{array}{l}16 \\
20\end{array}$ \\
\hline
\end{tabular}

${ }_{1}$ All treatments received $100 \mathrm{lb}$. each of $\mathrm{N}$ and $\mathrm{P}_{2} \mathrm{O}_{5}$ and $150 \mathrm{lb}$. of $\mathrm{K}_{2} \mathrm{O}$ per acre.

$2 \mathrm{~A}$ double sulfate of potash and magnesia containing not less than 21 percent of $\mathrm{K}_{2} \mathrm{O}$ and not less than 53 percent of magnesium sulfate.

- Fritted trace elements, a relatively insoluble powdered glass containing $\mathrm{Mn}, \mathrm{Fe}$, $\mathrm{Zn}, \mathrm{Cu}, \mathrm{B}$, and $\mathrm{Me}$.

A commercial minor-element mixture for soil application containing $\mathrm{Mg}, \mathrm{Fe}, \mathrm{Zn}$ $\mathrm{Cu}, \mathrm{B}$, and Mo.

For the Aibonito experiments on a Juncos clay the use of 1 ton of lime $\left(\mathrm{CaCO}_{3}\right)$ gave significant yield increases (table 5). Only in the second experiment which occurred in an extremely dry year did the response fail 
to prove significant. The use of 2 tons of lime was no more effective than 1 ton. In both the Caguas and Gurabo experiments lime failed to increase yields. In fact, a significant decrease in yield was obtained in the Gurabo experiment.

The use of gypsum to supply calcium and sulfur without influencing $\mathrm{pH}$ failed to effect any significant yield increase at Caguas or Gurabo. When gypsum was combined with lime no increases in yields were obtained.

Lime when added to filter-press cake decreased yields quite significantly (table 5). Filter-press cake contains about 3 percent of $\mathrm{CaO}(6)$, which, when combined with 1 ton of lime, depressed tobacco yields at Aibonito.

\section{MINOR ELEMENTS}

The use of certain minor elements failed to increase tobacco yields (table 5). Magnesium, long noted as needed for good tobacco growth, was not proved deficient in the soils tested when applied either as the oxide or the sulfate. Borex used at the rate of 35 pounds per acre failed to increase yields at Aibonito. Even complete minor-element mixtures, both as a slowly available material, fritted trace elements, or the more available salts, Miller Mineral Mix, did not augment yields, indicating no particular deficiency of the minor elements applied in the soils tested at Caguas and Gurabo.

\section{DISCUSSION}

It would be unrealistic if the authors did not mention in this connection the great influence displayed by rainfall on tobacco yields in Puerto Rico. Unaided by irrigation, the tobacco crop is at the mercy of the rainfall which occurs during the growth of the crop. In Puerto Rico this is quite generally deficient or excessive. This has much to do with the efficiency of the use made by the tobacco plant of the fertilizer applied. Tobacco is a fast-growing, shallow-rooted plant which requires much water for its development. Water deficiencies limit the uptake of the fertilizer nutrients present in the soil, and may cause damage to the roots by "burning" from the increase in the inorganic nutrient concentration of the soil solution. Excessive rainfall causes a leaching of the more soluble fertilizer elements nitrogen such as $\mathrm{NO}_{3}$, but not $\mathrm{NH}_{4}$. In a poorly drained soil rainfall effects on the yields of tobacco can be found in the first 3 experiments at Aibonito. The results were as follows:

$\begin{array}{ccc}\text { Experiment } & \text { Rainfall (inches) } & \text { Tobacco } \\ 1,1951 & 12.4 & 11.9 \\ 2,1952 & 5.2 & 9.9 \\ 3,1953 & 15.1 & 17.7\end{array}$


Highest yields of tobacco were obtained in the third experiment which had the highest rainfall during the growth of the crop; the lowest yields were in the second where rainfall was also lowest.

The rainfall available for the tobacco crop not only influenced yields in general, but also had an influence on the efficiency of the fertilizer applied. The response of 50 pounds of nitrogen per acre over no-nitrogen increased

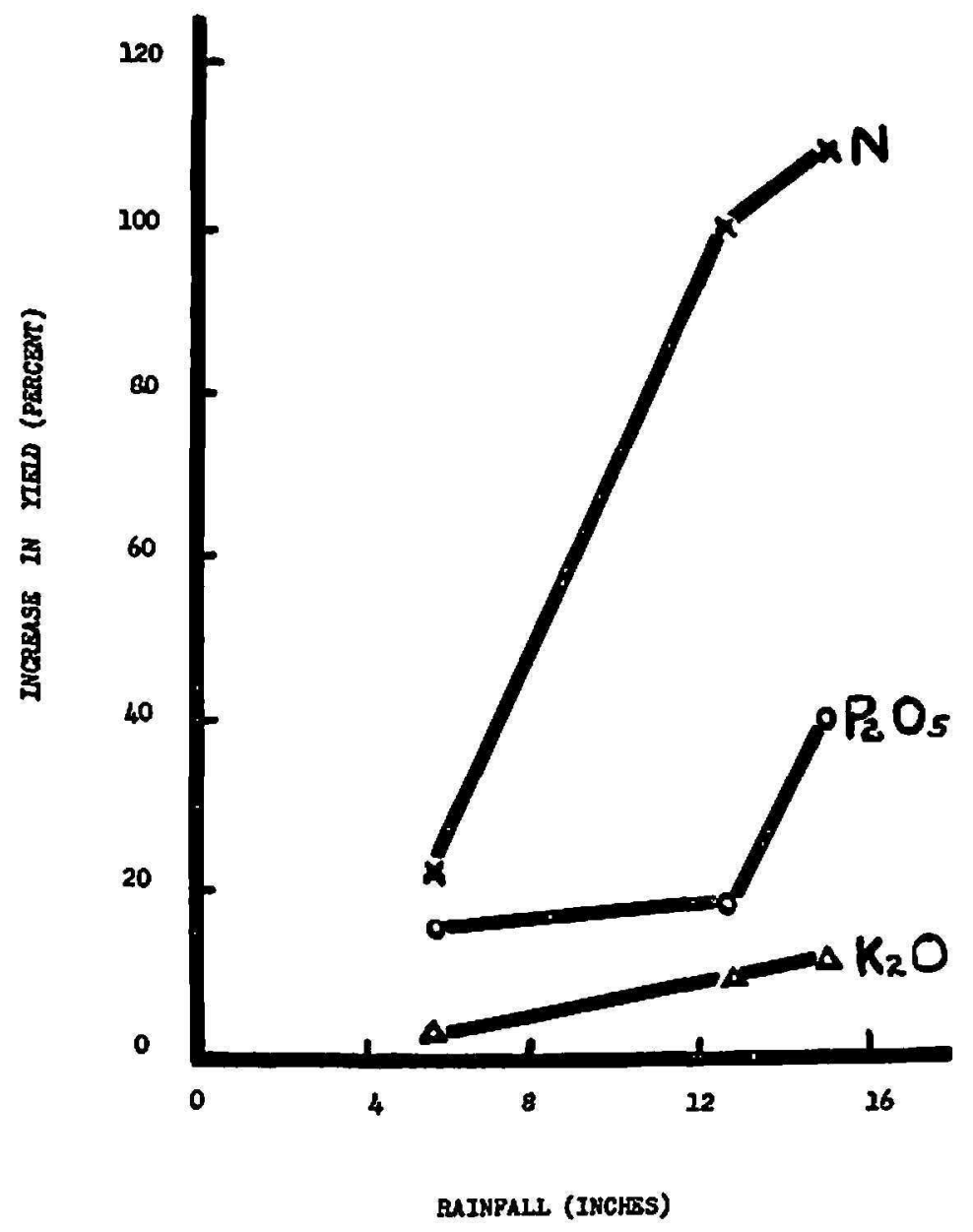

FIG. 1.-Influence of rainfall on the efficiency of fertilizer-N- $-\mathrm{P}_{2} \mathrm{O}_{5}-\mathrm{K}_{2} \mathrm{O}$-in increasing yields of tobacco. The percentage increase in yield is based on applications of 50 pounds per acre of the principal fertilizer elements.

greatly as the rainfall increased (see fig. 1). The response to 50 pounds of $\mathrm{P}_{2} \mathrm{O}_{6}$ per acre showed some increases from rainfall, but not as great as for nitrogen.

\section{SUMMARY}

A series of fertilizer experiments with tobacco revealed the following highlights as to the influence of the fertilizer on yields of barn-cured tobacco per acre:

1. On a Juncos clay there was a significant response to $\mathbf{5 0}$ pounds of $\mathrm{N}$ and of $\mathrm{P}_{2} \mathrm{O}_{5}$ per acre, respectively. Potash did not influence yields. 
2. A single fertilizer application at time of planting gave yields of tobacco equal to those where the fertilizer was applied 10 days after planting or was split into two applications.

3. No source of nitrogen, either inorganic, organic, or mixtures of both, proved superior to ammonium sulfate for tobacco.

4. No source of potassium, either inorganic, organic, or mixtures, increased yields of tobacco.

5. The use of 1 ton of lime increased yields significantly on a Juncos clay, but not on a Caguas or Mabí clay.

6. The use of gypsum alone, or in combination with lime, failed to increase yields.

7. Magnesium, boron, and complete minor-element mixtures failed to increase tobacco yields.

8. The amount of rainfall during the growth of the tobacco crop influenced both yields in general and the response of the tobacco to the fertilizer applied. Higher yields and fertilizer responses were obtained with increasing rainfall.

\section{RESUMEN}

En una serie de experimentos sobre abonos para tabaco resultaron los siguientes puntos relevantes en cuanto a los efectos de estos abonos sobre los rendimientos por cuerda del tabaco curado en rancho:

1. En suelo Juncos-arcilloso el tabaco respondio significativamente a la aplicación de 50 libras de $\mathrm{N}$ y $\mathrm{P}_{2} \mathrm{O}_{5}$ por acre, respectivamente. La potasa no influyó sobre los rendimientos.

2. Una sola aplicación de abono, al tiempo de la siembra, produjo rendimientos iguales a cuando el abono se aplicó todo a los 10 días después de la siembra o se dividió para aplicarse en dos ocasiones.

3. Ninguna fuente de nitrógeno orgánico, o mezclas de las mismas, probó ser superior al sulfato de amonio para el tabaco.

4. Ninguna fuente de potasio orgánico o inorgánico, o mezclas de las mismas, aumentó los rendimientos del tabaco.

5. El uso de una tonelada de cal aumentó los rendimientos significativamente en un suelo Juncos-arcilloso, pero no tuvo el mismo efecto en los suelos Caguas y Mabí arcilloso.

6. El uso de yeso solo o en combinación con cal, no aumentó los rendimientos.

7. El magnesio, el boro y las mezclas combinadas de elementos menores no aumentaron los rendimientos del tabaco.

8. La cantidad de lluvia durante todo el período de desarrollo de la siembra de tabaco influyó tanto en los rendimientos generales como en la manera de responder el tabaco al abono aplicado. Al aumentar la lluvia 
se obtuvieron rendimientos más altos y efectos mayores de la aplicación de abono.

\section{LITERATURE CITED}

1. Anderson, P. J., Growing Tobacco in Connecticut, Conn. Agr. Exp. Sta. Bul. 56 x, pp. 1-109, Dec. 1952.

2. Clark, F., Fertilizer Tests with Flue-Cured Tobacco, Univ. Fla. Agr. Exp. Sta. Bul. 512, pp. 1-27, Jan. 1953.

3. Espinet, G. R., Analysis Económico del Cultivo del Tabaco en Puerto Rico, Univ. P.R. Agr. Exp. Sta., Bul. 133, pp. 1-40, Apr. 1956.

4. Johnson, J., and Ogden, W. B., A 10-Year Fertilizer Experiment on Tobacco, Agr. Exp. Sta. Univ. Wis. Research Bul. 141, pp. 1-24, Dec. 1941.

5. Mathews, E. M., A balanced fertilizer for bright tobacco, Better Crops with Plant Food, 22 (5) 6-9, 1938.

6. Samuels, G., Filter-press cake as a fertilizer, J. Agr. Univ. P.R. 39 (4) 198-213, 1955.

7. Swanback, T. R., The Nitrogen Fertilization of Connecticut tobacco, Conn. Agr. Exp. Sta., Bul. 559, pp. 1-23, June 1952. 